\title{
PENGARUH LINGKUNGAN KERJA FISIK DAN NON FISIK DENGAN MOTIVASI SEBAGAI VARIABEL MODERATING TERHADAP KINERJA PEGAWAI P.T. PEGADAIAN (PERSERO) KANTOR CABANG PALEMBANG
}

\author{
Oleh: \\ Nisa' Ulul Mafra \\ Fakultas Ekonomi Universitas PGRI Palembang \\ Email: nisaulul29@gmail.com
}

\begin{abstract}
ABSTRAK
Penelitian ini berjudul Pengaruh Lingkungan Kerja Fisik dan Nonfisik dengan Motivasi Sebagai Variabel Moderating Terhadap Kinerja Pegawai Pegadaian PT (Persero) Kantor Cabang Palembang. Tujuan penelitian ini adalah selain untuk mengetahui pengaruh lingkungan kerja fisik dan nonfisik secara bersama-sama dan secara parsial terhadap kinerja pegawai juga untuk mengetahui pengaruh motivasi dalam memoderasi hubungan lingkungan kerja fisik dan nonfisik tersebut. Metod e penelitian ini menggunakan metode multiple regresssion model yaitu desain penelitian yang akan mengungkapkan pengaruh kolektif variabel bebas terhadap satu variabel terikat. Data yang digunakan yaitu data primer dan data skunder yang dikumpulkan melalui kuesionerdan data dari kepegawaian P.T. Pegadaian. Jumlah populasi sekaligus sebagai sampel seluruh pegawai sebanyak 31 orang pegawai. Hasil penelitian menunjukkan bahwa kinerja pegawai PT. Pegadaian (Persero) Kantor Cabang Palembang dipengaruhi oleh lingkungan kerja fisik dan nonfisik dan dengan dimoderasi motivasi memperkuat pengaruh kedua variabel tersebut terhadap kinerja pegawai. Hal ini dibuktikan dengan analisis regresi lingkungan kerja fisik dan sebelum dan sesudah dimoderasi oleh motivasi.
\end{abstract}

\section{Kata Kunci: Lingkungan Kerja Fisik, Lingkungan Kerja Nonfisik, Motivasi dan Kinerja Pegawai}

\section{PENDAHULUAN}

PT. Pegadaian (Persero) yang
merupakan sebuah BUMN sektor
keuangan Indonesia yang bergerak pada
tiga lini bisnis perusahaan yaitu
pembiayaan, emas dan aneka jasa dengan Motto: Mengatasi Masalah Tanpa Masalah. Perusahaan umum pegadaian adalah satu-satunya badan usaha di Indonesia yang secara resmi mempunyai izin untuk melaksanakan kegiatan lembaga keuangan berupa pembiayaan dalam bentuk penyaluran dana ke masyarakat atas dasar hukum gadai seperti dimaksud dalam Kitab Undang-undang Hukum Perdata Pasal 1150. Dalam setiap pelaksanaan kegiatan usahanya, PT. Pegadaian (Persero) harus selalu berpedoman pada prinsip-prinsip Good Corporate Governance (GCG) untuk menghindari praktik-praktik gratifikasi. Pelaksanaan pengendalian gratifikasi yang baik membutuhkan check and balance pada setiap proses bisnis, di tiap level maupun fungsi. Penerapan Good Corporate Governance (GCG) secara sistematis dan konsisten merupakan kebutuhan yang harus dilaksanakan.

Demikian pula yang dilakukan oleh PT. Pegadaian (Persero) Kantor Cabang Palembang sebagai salah satu cabang PT. Pegadaian (Persero) juga berkomitmen untuk menjalankan semua kesepakatan tersebut. Untuk penerapan Good Corporate Governance (GCG) itu, tidak terlepas dari budaya organisasi yang berlaku di dalam organisasi itu sendiri. Budaya menurut Schein (2010:5) adalah fenomena dinamis dalam kondisi "disini dan saat ini" dan sebuah latar belakang 
struktur paksaan yang berpengaruh pada kelompok melalui beberapa cara. Good Corporate Governance (GCG) dapat dicapai selain didukung oleh lingkungan kerja yang merupakan bagian dari budaya organisasi tetapi perlu juga dimoderasi oleh motivasi agar kinerja yang diharapkan dapat tercapai sesuai dengan visi dan misi perusahaan. Sutrisno (2015: 118) mendefinisikan lingkungan kerja sebagai keseluruhan sarana dan prasarana kerja yang ada di sekitar pegawai yang sedang melakukan pekerjaan yang dapat mempengaruhi pelaksanaan pekerjaan. Lingkungan kerja sendiri dapat dipisahkan menjadi dua yaitu lingkungan kerja fisik dan lingkungan kerja nonfisik. Sedarmayanti (2011:26) menyatakan bahwa lingkungan kerja fisik adalah semua berbentuk fisik yang terdapat di sekitar tempat kerja yang mempengaruhi pegawai baik secara langsung maupun tidak langsung. Sedangkan lingkungan kerja nonfisik merupakan semua keadaan yang terjadi yang berkaitan dengan hubungan kerja, baik hubungan dengan atasan maupun sesama rekan kerja, ataupun hubungan dengan bawahan. Lingkungan kerja yang sehat dan baik secara otomatis akan berpengaruh terhadap pencapaian kinerja pegawai.

Kinerja pegawai dapat didefinisikan sebagai pencapaian atau prestasi seseorang berkenaan dengan tugas-tugas yang dibebankan kepadanya Marwansyah (2012:228). Demikian pula motivasi yang dapat mempengaruhi kinerja pegawai. Motivasi sendiri merupakan kondisi atau energi yang menggerakkan diri pegawai yang terarah atau tertuju untuk mencapai tujuan organisasi perusahaan (Mangkunegara, 2014:61). Hal ini sesuai dengan penelitian Koesmono (2007) dengan hasil analisis data terhadap
135 orang perawat dapat dijelaskan bahwa Motivasi sebagai moderate variable ternyata secara reciprocal dan signifikan ikut mempengaruhi lemah atau kuatnya pengaruh stres kerja $(0,094)$ terhadap kepuasan kerja $(0,693)$.

Dari uraian di atas, peneliti berpendapat bahwa lingkungan kerja fisik dan nonfisik serta dengan dimoderasi motivasi merupakan suatu yang penting dalam meningkatkan kinerja pegawai. Tetapi pada kenyataannya perlu dilakukan pembenahan pada lingkungan kerja, misalnya ruangan kerja yang sempit, suasana kerja yang monoton dan masih perlu membina hubungan yang baik antara pegawai. Keadaan ini dapat menyebabkan ketidakleluasan dalam bekerja yang tentunya dapat mempengaruhi kinerja pegawai. Selain itu kantor cabang ini belum memiliki ruangan humas sendiri karena masih tergabung dengan humas Kantor Wilayah PT. Pegadaian (Persero).

Tujuan yang ingin dicapai dalam penelitian ini adalah:

1. Untuk Mengetahui Pengaruh Lingkungan Kerja Fisik Terhadap Kinerja Pegawai PT. Pegadaian (Persero) Kantor Cabang Palembang.

2. Untuk Mengetahui Pengaruh Lingkungan Kerja Nonfisik Terhadap Kinerja Pegawai PT. Pegadaian (Persero) Kantor Cabang Palembang.

3. Untuk mengetahui Pengaruh Lingkungan Kerja Fisik dan Nonfisik Terhadap Kinerja Pegawai PT. Pegadaian (Persero) Kantor Cabang Palembang?

4. Untuk Mengetahui Pengaruh Lingkungan Kerja Fisik dengan dimoderasi Motivasi Terhadap Kinerja Pegawai PT. Pegadaian (Persero) Kantor Cabang Palembang. 
5. Untuk Mengetahui Pengaruh Lingkungan Kerja Fisik dengan dimoderasi Motivasi Terhadap Kinerja Pegawai PT. Pegadaian (Persero) Kantor Cabang Palembang.

\section{METODE PENELITIAN}

Metode yang digunakan dalam penelitian ini adalah penelitian asosiatif (Sugiyono,2017:6) untuk mengetahui pengaruh kolektif variabel bebas terhadap variabel terikat. Jumlah sampel yang digunakan dalam penelitian ini sama dengan populasi yaitu seluruh pegawai PT. Pegadaian (Persero) Kantor Cabang Palembang yang berjumlah 31 orang. Sugiyono (2017: 80) mendefinisikan populasi sebagai wilayah generalisasi yang terdiri atas objek atau subjek yang mempunyai kualitas dan karakteristik tertentu yang ditetapkan oleh peneliti untuk dipelajari dan kemudian ditarik kesimpulannya. Sugiyono (2017: 81) menyatakan sampel adalah bagian dari jumlah dan karakteristik yang dimiliki oleh populasi.

Sumber pengumpulan data yang digunakan dalam penelitian ini yaitu data primer dan data sekunder (Sanusi, 2014:104). Data primer yang dikumpulkan oleh peneliti yaitu jawaban responden yaitu pegawai PT. Pegadaian (Persero) Kantor Cabang Palembang. Sedangkan data sekunder adalah data yang tersedia dan dikumpulkan oleh pihak lain, berupa data yang tersedia di lokasi penelitian.

Teknik pengumpulan data yang digunakan adalah kuesioner yaitu pengumpulan data yang diwakili oleh daftar pertanyaan/pernyataan yang sudah disusun secara cermat terlebih dahulu (Sanusi, 2014:109) dan dokumentasi yaitu berupa rekapitulasi personalia, struktur organisasi, peraturan-peraturan, riwayat perusahaan dan sebagainya (Sanusi, 2014:114).

Sebelum hasil instrumen penelitian tersebut digunakan pada proses pengujian hipotesis, terlebih dahulu dilakukan uji instrumen yang meliputi:

1. Uji Validitas, adalah suatu instrumen yang digunakan untuk mengetahui seberapa tepat suatu alat ukur dapat melakukan fungsinya (Singgih, 2010: 141)

2. Uji Reliabilitas, sebagai alat untuk mengukur suatu kuesioner yang merupakan indikator dari variabel konstruks (Ghozali,2011: 41).

Teknik Analisis Data terdiri dari:

a) Uji Normalitas. Data yang bertujuan untuk menguji apakah data yang akan digunakan dalam model regresi berdistribusi normal atau tidak (Ghozali, 2011:110).

b) Uji Multikolinieritas yaitu pedoman umum (rule of thumb) untuk batasan nilai VIF dan tolerance agar model regresi terbebas dari persoalan multikolinearitas adalah dibawah 10 untuk VIF dan diatas $10 \%$ untuk tolerance (Ghozali, 2011:107).

c) Uji Heteroskedastisitas yang bertujuan untuk mengetahui apakah dalam model regresi terjadi ketidaksamaan varians dan residual pengamatan yang lain dengan dasar pengambilan keputusan (Singgih,2010:210)

\section{Metode Analisis}

Metode yang digunakan dalam penelitian ini adalah metode analisis kuantitatif, metode ini merupakan suatu metode analisis data yang menggunakan angka-angka agar pemecahan masalah dapat dilakukan secara pasti dengan perhitungan matematik. Adanya tahapan 
analisis kuantitatif yang digunakan untuk menganalisis data dalam penelitian ini adalah: analisis regresi berganda (multiple regresssion model) untuk mengetahui pengaruh lingkungan kerja fisik $\left(\mathrm{X}_{1}\right)$ dan lingkungan kerja nonfisik $\left(\mathrm{X}_{2}\right)$ terhadap kinerja pegawai (Y) PT. Pegadaian (Persero) Kantor Cabang Palembang dengan motivasi $\left(\mathrm{X}_{3}\right)$ sebagai variabel moderating dihitung dengan rumus regresi berganda (Sugiyono, 2017:293), yakni:

$\mathrm{Y}=\alpha+b_{1} \mathrm{X}_{1}+\mathrm{b}_{2} \mathrm{X}_{2}+\mathrm{b}_{3} \mathrm{X}_{1} . \mathrm{X}_{2}+\varepsilon$

$\mathrm{Y}=\alpha+b_{1} X_{1}+b_{2} X_{2}+b_{3} X_{1} . X_{3}+$ $\mathrm{b}_{4} \mathrm{X}_{2} \mathrm{X}_{3}+\varepsilon$

Dimana:

$\begin{array}{ll}\mathrm{Y} & =\text { Kinerja Pegawai } \\ \alpha & =\text { Konstanta } \\ \mathrm{b}_{1}, \mathrm{~b}_{2}, \mathrm{~b}_{3}, \mathrm{~b}_{4}, \mathrm{~b}_{5} & =\text { Koefisien Regresi } \\ \mathrm{X}_{1} & =\text { Lingkungan Kerja Fisik } \\ \mathrm{X}_{2} & =\text { Lingkungan Kerja } \\ & \text { Nonfisik } \\ \mathrm{X}_{3} & =\text { Motivasi (moderasi) } \\ \boldsymbol{\varepsilon} & =\text { Error Term }\end{array}$

HASIL DAN PEMBAHASAN

\section{Karakteristik Responden}

\section{Karakteristik Responden Berdasarkan Jenis Kelamin}

Karakteristik

responden

berdasarkan jenis kelamin dapat diketahui dari 31 responden bahwa 14 responden berjenis kelamin laki-laki (45,16\%), sedangkan 17 responden berjenis kelamin perempuan $(54,84 \%)$. Dari data sampel tersebut memberikan gambaran bahwa pegawai PT. Pegadaian (Persero) Kantor Cabang Palembang mayoritas dengan jenis kelamin perempuan.

\section{Karakteristik Responden Berdasarkan Usia}

Karakteristik responden berdasarkan usia dapat diketahui bahwa untuk usia responden yang dominan adalah yang berusia antara $20-30$ tahun sebanyak 16 orang $(51,61 \%)$, diikuti dengan usia responden $31-40$ tahun sebanyak 11 orang $(35,49 \%)$, kemudian usia 41- 50 tahun sebanyak 4 orang (12,90\%). Dari data sampel tersebut memberikan gambaran bahwa pegawai PT. Pegadaian (Persero) Kantor Cabang Palembang mayoritas dengan usia antara 20-30 tahun.

\section{Karakteristik Responden Berdasarkan Tingkat Pendidikan}

Karakteristik

responden

berdasarkan tingkat pendidikan dapat dijelaskan bahwa pendidikan responden pada tingkat SMA sebanyak 3 orang $(9,68 \%)$, diikuti DI/II/III sebanyak 7 orang $(22,58 \%)$ kemudian strata 1 (S1) sebanyak 21 orang $(67,74 \%)$. Dari data sampel tersebut memberikan gambaran bahwa pegawai PT. Pegadaian (Persero) Kantor Cabang Palembang mayoritas dengan tingkat pendidikan Strata 1 (S1).

\section{Deskripsi Variabel Penelitian}

Untuk lebih jelasnya dapat dilihat dari tabel hasil rekapitulasi jawaban responden dari setiap variabel sebagai berikut:

\section{Rekapitulasi Jawaban Responden}

Mayoritas pegawai menyatakan setuju bahwa lingkungan kerja fisik $\left(\mathrm{X}_{1}\right)$ pada P.T Pegadaian (Persero) Kantor Cabang Palembang sudah baik dengan rata-rata yang diperoleh dari 12 pernyataan diketahui seluruh pernyataan responden menyatakan sangat baik dan baik dengan rata-rata nilai 4,00 walaupun pada beberapa penyataan menunjukkan keraguraguan yang cukup tinggi (22,6\%). Sedangkan untuk lingkungan kerja nonfisik $\left(\mathrm{X}_{2}\right)$ sudah baik dengan rata-rata 
dari 4 pernyataan diketahui secara keseluruhan responden menyatakan baik dengan rata-rata nilai 4,00 walaupun pada beberapa pernyataan menunjukkan keraguraguan yang cukup tinggi (32,3\%). Selanjutnya motivasi kerja $\left(\mathrm{X}_{3}\right)$ sudah baik karena rata-rata yang diperoleh dari 6 pernyataan diketahui secara keseluruhan responden menyatakan sangat baik dan baik dengan rata-rata nilai 4,00 walaupun pada beberapa penyataan menunjukkan keragu-raguan yang cukup tinggi $(19,4 \%)$. Untuk kinerja pegawai (Y) rata-rata yang diperoleh dari 10 pernyataan diketahui seluruh pernyataan responden menyatakan sangat baik dan baik dan rata-rata keseluruhan responden menyatakan baik dengan rata-rata nilai 4,01. Hal ini bermakna bahwa mayoritas pegawai menyatakan setuju bahwa kinerja pegawai sudah baik walaupun pada beberapa penyataan terdapat keragu-raguan dan ketidak setujuan yang cukup tinggi $(16,1 \%)$.

\section{Uji Validitas}

Kriteria pengujian validitas dilakukan dengan cara membandingkan $r_{\text {hitung dan }} r_{\text {tabel }}(0,355)$. Hasil yang diperoleh menunjukkan bahwa lingkungan kerja fisik dengan 12 item pernyataan, nonfisik dengan 4 item pernyataan, motivasi dengan 6 item pernyataan dan kinerja pegawai 10 pernyataan yang diajukan kepada 31 responden menyatakan semuanya valid dan dapat digunakan untuk meneruskan penelitian.

\section{Uji Reliabilitas}

Hasil pengujian data reliabilitas yang dilakukan maka dapat disimpulkan untuk keempat variabel memiliki Nilai Cronbach's di atas 0,6 pada taraf nyata alpha $(\alpha)=5 \%$. Dengan demikian dapat disimpulkan semua item pernyataan yang ada pada instrumen tersebut dinyatakan reliabel dan dapat dijadikan sebagai alat ukur dalam analisis selanjutnya.

\section{Pengujian Asumsi Klasik}

Berikut akan disajikan hasil pengujian asumsi klasik terhadap model regresi:

\section{Uji Normalitas}

Secara rinci hasil pengujian normalitas dapat dilihat pada tabel berikut:

Tabel 2 Hasil Pengujian Normalitas

\begin{tabular}{lccc}
\hline \hline Variabel & Nilai Signifikan & K- & Nilai \\
Standarisasi & Keterangan \\
\hline Lingkungan Kerja Fisik $\left(\mathrm{X}_{1}\right)$ & 0.663 & 0.05 & Normal \\
Lingkungan kerja nonfisik $\left(\mathrm{X}_{2}\right)$ & 0.549 & 0.05 & Normal \\
Motivasi Kerja $\left(\mathrm{X}_{3}\right)$ & 0.309 & 0.05 & Normal \\
Kinerja Pegawai $(\mathrm{Y})$ & 0.160 & 0.05 & Normal \\
\hline
\end{tabular}

Sumber : Data primer yang diolah, 2017

Hasil uji normalitas data menggunakan One Sample Kolmogorov Smirnov Test, sebagaimana tersaji pada tabel diatas dapat disimpulkan bahwa semua variabel memiliki data normal dikarenakan semua data tersebut memiliki Asymp.Sig $>(\alpha) 0,05$.
Uji Multikolinearitas

Nilai tolerance menunjukkan variasi variabel independen dijelaskan oleh variabel independen lainnya dalam model regresi dengan mengabaikan variabel dependen. 
Tabel 3 Hasil Uji Multikolinearitas

\begin{tabular}{lccc}
\hline \hline \multicolumn{1}{c}{ Variabel bebas } & Tolerance & VIF & Keterangan \\
\hline Lingkungan Kerja Fisik $\left(\mathrm{X}_{1}\right)$ & 0.725 & 1.380 & Non multikolineritas \\
\hline Lingkungan Kerja Nonfisik $\left(\mathrm{X}_{2}\right)$ & 0.526 & 1.901 & Non multikolineritas \\
Motivasi Kerja $\left(\mathrm{X}_{3}\right)$ & 0.455 & 2.199 & Non multikolineritas \\
\hline
\end{tabular}

Sumber : Data primer yang diolah, 2017

Hasil uji multikolinearitas diperoleh nilai Variance Inflation Factor (VIF) pada semua variabel independen berada tidak jauh dari nilai 1 atau lebih kecil dari 10 dan angka tolerance mendekati 1 maka dapat diambil kesimpulan bahwa tidak terdapat gejala multikolinearitas, sehingga regresi sah untuk digunakan.

\section{Uji Heteroskedastisitas}

Untuk mendeteksi adanya heteroskedastisitas dilakukan dengan melihat ada tidaknya pola tertentu pada grafik scatterplot.

\section{Gambar 1 Hasil Pengujian Heterokedastisitas}

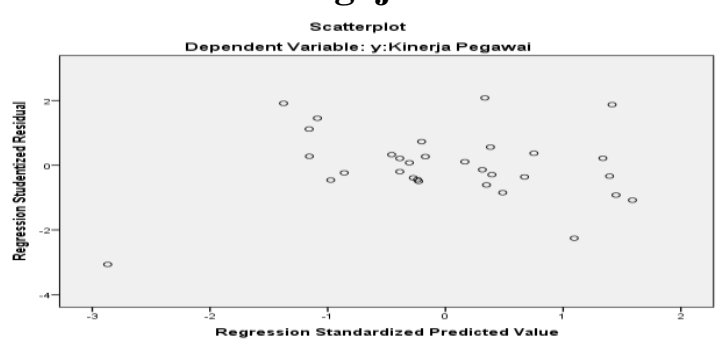

Hasil uji heteroskedastisitas dengan menggunakan uji Scatterplot menunjukkan tidak ada pola tertentu seperti titik yang membentuk suatu pola teratur (bergelombang, melebar kemudian menyempit) serta titik menyebar di atas dan di bawah angka 0 pada sumbu $\mathrm{Y}$, maka dapat disimpulkan bahwa tidak terjadi problem heteroskedasitas.

\section{Hasil Analisis Data}

Dalam penelitian ini data yang diperoleh dianalisis dengan menggunakan teknik statistik yaitu analisis regresi seperti pada tabel dibawah ini:

\section{a. Regresi Berganda}

Berdasarkan hasil regresi dari data yang diolah diperoleh hasil sebagai berikut:

Tabel 4 Hasil Analisis Regresi Berganda

\begin{tabular}{lrrr}
\hline \hline & \multicolumn{2}{c}{ Unstandardized Coefficients } & Standardized Coefficients \\
\cline { 2 - 4 } Model & \multicolumn{1}{c}{ B } & Std. Error & Beta \\
\hline (Constant) & -11.873 & 6.035 & .712 \\
Lingkungan kerja fisik $\left(\mathrm{X}_{1}\right)$ & .794 & .118 & .274 \\
Lingkungan kerja nonfisik $\left(\mathrm{X}_{2}\right)$ & .861 & .332 & \\
\hline
\end{tabular}

Sumber : Data primer yang diolah, 2017

Berdasarkan tabel 13, maka persamaan regresi dalam penelitian ini adalah :

$$
Y=-11,873+0,794 X_{1}+0,861 X_{2}
$$

Model tersebut menunjukkan bahwa nilai besaran koefisien regresi 
sebesar -11,873 dapat diartikan bahwa jika lingkungan kerja $\left(\mathrm{X}_{1}\right)$ dan nonfisik $\left(\mathrm{X}_{2}\right)$ sama dengan nol maka kinerja pegawai mengalami peningkatan sebesar $-11,873$ satu-satuan. Sedangkan regresi 0,794 menunjukkan lingkungan kerja fisik berpengaruh positif terhadap kinerja pegawai dan jika mengalami peningkatan sebesar satu satuan maka kinerja pegawai (Y) akan mengalami peningkatan sebesar 0,794 satuan, begitu pula sebaliknya.
Selanjutnya nilai besaran koefisien regresi sebesar 0,861 dapat diartikan bahwa lingkungan kerja nonfisik $\left(\mathrm{X}_{2}\right)$ berpengaruh positif terhadap kinerja pegawai (Y). Hal ini menunjukkan bahwa apabila lingkungan kerja nonfisik mengalami peningkatan sebesar satusatuan, maka kinerja pegawai mengalami peningkatan sebesar 0,861 satuan, begitu pula sebaliknya.

\section{b. Regresi Moderasi Tahap 1}

Tabel 5 Hasil Analisis Regresi Berganda Tahap 1

\begin{tabular}{|c|c|c|c|c|c|c|}
\hline \multirow[b]{3}{*}{ Model } & \multicolumn{3}{|c|}{ Sebelum Dimoderasi } & \multicolumn{3}{|c|}{ Setelah Dimoderasi } \\
\hline & \multicolumn{2}{|c|}{$\begin{array}{l}\text { Unstandardized } \\
\text { Coefficients }\end{array}$} & \multirow{2}{*}{$\begin{array}{l}\text { Standardized } \\
\text { Coefficients } \\
\text { Beta }\end{array}$} & \multicolumn{2}{|c|}{$\begin{array}{l}\text { Unstandardized } \\
\text { Coefficients }\end{array}$} & $\begin{array}{l}\text { Standardized } \\
\text { Coefficients }\end{array}$ \\
\hline & $\bar{B}$ & Std. Error & & B & Std. Error & Beta \\
\hline (Constant) & -9.818 & 5.893 & & -163.555 & 36.915 & \\
\hline $\begin{array}{l}\text { Lingkungan kerja } \\
\text { fisik }\left(\mathrm{X}_{1}\right)\end{array}$ & .760 & .129 & .686 & 3.914 & .758 & 3.509 \\
\hline Motivasi $\left(\mathrm{X}_{3}\right)$ & .539 & .234 & .267 & 7.172 & 1.591 & 3.550 \\
\hline Interaksi $\left(\mathrm{X}_{1} * \mathrm{X}_{3}\right)$ & & & & -.136 & .032 & -5.345 \\
\hline
\end{tabular}

Sumber : Data primer yang diolah, 2017

Berdasarkan tabel 9, sebelum dimoderasi motivasi maka persamaan regresi dalam penelitian ini adalah :

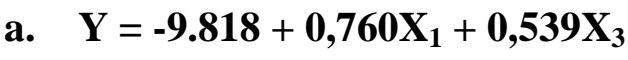

Model diatas menunjukkan bahwa nilai besaran koefisien regresi sebesar 9,818 dapat diartikan bahwa jika lingkungan kerja $\left(\mathrm{X}_{1}\right)$ dan motivasi $\left(\mathrm{X}_{3}\right)$ sama dengan nol maka kinerja pegawai mengalami peningkatan sebesar $-9,818$ satu-satuan. Sedangkan regresi 0,760 menunjukkan lingkungan kerja fisik berpengaruh terhadap kinerja pegawai dan jika lingkungan kerja mengalami peningkatan sebesar satu satuan maka kinerja pegawai (Y) akan mengalami peningkatan sebesar 0,760 satuan, begitu pula sebaliknya. Nilai besaran koefisien regresi sebesar 0,539 dapat diartikan bahwa motivasi $\left(\mathrm{X}_{3}\right)$ berpengaruh positif terhadap kinerja pegawai (Y). Hal ini menunjukkan bahwa apabila motivasi mengalami peningkatan sebesar satusatuan, maka kinerja pegawai mengalami peningkatan sebesar 0,539 satuan, begitu pula sebaliknya.

\section{b. $\quad Y=-163.555+3,914 X_{1}+7.172 X_{3}-$ $\mathbf{0 , 1 3 6 X _ { 1 }} \cdot X_{3}$ \\ Nilai besaran menunjukkan} koefisien regresi sebesar -163,555 dapat diartikan bahwa jika lingkungan kerja $\left(\mathrm{X}_{1}\right)$ dan motivasi $\left(\mathrm{X}_{3}\right)$ sama dengan nol maka kinerja pegawai mengalami peningkatan sebesar -163,555 satu-satuan. Sedangkan regresi 3,914 menunjukkan lingkungan kerja fisik berpengaruh terhadap kinerja pegawai dan jika lingkungan kerja fisik mengalami peningkatan sebesar satu satuan maka kinerja pegawai (Y) akan mengalami peningkatan sebesar 3,914 
satuan, begitu pula sebaliknya. Nilai koefisien regresi sebesar 7,172 dapat diartikan bahwa motivasi $\left(\mathrm{X}_{3}\right)$ berpengaruh positif terhadap kinerja pegawai (Y). Hal ini menunjukkan bahwa apabila motivasi mengalami peningkatan sebesar satusatuan, maka kinerja pegawai mengalami peningkatan sebesar 7,172 satuan, begitu pula sebaliknya.

Pada kedua tabel diatas terdapat perbedaan nilai yang sangat mencolok antara lingkungan kerja fisik sebelum dimoderasi oleh motivasi $\left(\mathrm{X}_{1}\right)$ sebesar 0,760 satuan dan setelah dimoderasi oleh motivasi $\left(\mathrm{X}_{1} \cdot \mathrm{X}_{3}\right)$ sebesar -0,136 maka regresi lingkungan kerja fisik meningkat menjadi sebesar 3,914 satuan. Artinya dengan dimoderasi oleh motivasi menyebabkan peningkatan kinerja pegawai sebesar 3,154 satuan. Hal ini membuktikan sumbangan yang besar dari motivasi terhadap lingkungan kerja fisik dalam meningkatkan kinerja pegawai.

\section{c. Regresi Moderasi Tahap 2}

\section{Tabel 6 Hasil Analisis Regresi Berganda Tahap 2}

\begin{tabular}{|c|c|c|c|c|c|c|}
\hline \multirow{3}{*}{ Model } & \multicolumn{3}{|c|}{ Sebelum Dimoderasi } & \multicolumn{3}{|c|}{ Setelah Dimoderasi } \\
\hline & \multicolumn{2}{|c|}{$\begin{array}{c}\text { Unstandardized } \\
\text { Coefficients }\end{array}$} & \multirow{2}{*}{$\begin{array}{c}\begin{array}{l}\text { Standardized } \\
\text { Coefficients }\end{array} \\
\text { Beta }\end{array}$} & \multicolumn{2}{|c|}{$\begin{array}{l}\text { Unstandardized } \\
\text { Coefficients }\end{array}$} & \multirow{2}{*}{$\begin{array}{l}\text { Standardized } \\
\text { Coefficients } \\
\text { Beta }\end{array}$} \\
\hline & B & Std. Error & & B & Std. Error & \\
\hline (Constant) & 5.300 & 7.830 & & -193.089 & 56.680 & \\
\hline $\begin{array}{l}\text { Lingkungan kerja } \\
\text { Nonfisik }\left(\mathrm{X}_{2}\right)\end{array}$ & .770 & .623 & .245 & 13.471 & 3.642 & 4.282 \\
\hline Motivasi $\left(\mathrm{X}_{3}\right)$ & .918 & .400 & .455 & 8.869 & 2.281 & 4.390 \\
\hline Interaksi $\left(\mathrm{X}_{2} * \mathrm{X}_{3}\right)$ & & & & -.506 & .144 & -7.524 \\
\hline
\end{tabular}

Persamaan regresi sebelum dimoderasi motivasi dalam penelitian ini adalah :

a. $Y=5,300+0,770 X_{2}+\mathbf{0 , 9 1 8} X_{3}$

Model tersebut menunjukkan bahwa nilai besaran koefisien regresi sebesar 5,300 dapat diartikan bahwa jika lingkungan kerja nonfisik $\left(\mathrm{X}_{2}\right)$ dan motivasi $\left(\mathrm{X}_{3}\right)$ sama dengan nol maka kinerja pegawai mengalami peningkatan sebesar 5,300 satu-satuan. Sedangkan regresi 0,770 menunjukkan lingkungan kerja nonfisik berpengaruh positif terhadap kinerja pegawai dan jika lingkungan kerja nonfisik mengalami peningkatan sebesar satu satuan maka kinerja pegawai (Y) akan mengalami peningkatan sebesar 0,770 satuan, begitu pula sebaliknya.

Nilai besaran koefisien regresi sebesar 0,918 dapat diartikan bahwa motivasi $\left(\mathrm{X}_{3}\right)$ berpengaruh positif terhadap kinerja pegawai (Y). Hal ini menunjukkan bahwa apabila motivasi mengalami peningkatan sebesar satu-satuan, maka kinerja pegawai mengalami peningkatan sebesar 0,918 satuan, begitu pula sebaliknya.

\section{b. $Y=-193.089+13,471 X_{2}+8.869 X_{3}-$ $\mathbf{0 , 5 0 6 X _ { 2 } . X _ { 3 }}$ \\ Nilai besaran diatas menunjukkan} koefisien regresi sebesar -193.089 dapat diartikan bahwa jika lingkungan kerja nonfisik $\left(\mathrm{X}_{2}\right)$ dan motivasi $\left(\mathrm{X}_{3}\right)$ sama dengan nol maka kinerja pegawai mengalami peningkatan sebesar -193.089 satu-satuan. Sedangkan regresi 13,471 menunjukkan lingkungan kerja fisik nonfisik berpengaruh positif terhadap 
kinerja pegawai dan jika lingkungan kerja fisik nonfisik mengalami peningkatan sebesar satu satuan maka kinerja pegawai (Y) akan mengalami peningkatan sebesar 13,471 satuan. Sebaliknya jika lingkungan kerja fisik nonfisik mengalami penurunan sebesar satu satuan maka kinerja pegawai akan mengalami penurunan sebesar 13,471 satuan. Nilai besaran koefisien regresi sebesar 8.869 dapat diartikan bahwa motivasi $\left(\mathrm{X}_{3}\right)$ berpengaruh positif terhadap kinerja pegawai (Y). Hal ini menunjukkan bahwa apabila motivasi mengalami peningkatan sebesar satu-satuan, maka kinerja pegawai mengalami peningkatan sebesar 8,869 satuan. Apabila motivasi mengalami penurunan sebesar satu-satuan, maka kinerja pegawai mengalami penurunan sebesar 8,869 satuan.

Pada kedua tabel diatas terdapat perbedaan nilai yang sangat mencolok antara lingkungan kerja fisik nonfisik sebelum dimoderasi oleh motivasi $\left(\mathrm{X}_{1}\right)$ sebesar 0,770 satuan dan setelah dimoderasi oleh motivasi $\left(\mathrm{X}_{2} \cdot \mathrm{X}_{3}\right)$ sebesar 0,506 maka regresi lingkungan kerja nonfisik meningkat menjadi sebesar 8,869 satuan. Artinya dengan dimoderasi oleh motivasi menyebabkan peningkatan kinerja pegawai sebesar 8,099 satuan. Hal ini membuktikan sumbangan yang besar dari motivasi terhadap lingkungan kerja fisik dalam meningkatkan kinerja pegawai.

\section{b. Pengujian Hipotesis}

Dibawah ini disajikan hasil pengujian hipotesis yaitu uji $\mathrm{F}$ dan uji t:

\section{Hasil Uji F (Uji Bersama-sama)}

Tabel 7 Hasil Uji F (Uji Bersama-sama)

\begin{tabular}{lcclcll}
\hline \hline Model & $\begin{array}{l}\text { Sum of } \\
\text { Squares }\end{array}$ & Df & $\begin{array}{l}\text { Mean } \\
\text { Squares }\end{array}$ & F & Sig & Kriteria \\
\hline Regression & 492.248 & 2 & 246.124 & 39.240 & $.000^{\mathrm{b}}$ & $\mathrm{F}_{\text {hitung }}>\mathrm{F}_{\text {tabel }}=39,240>3,340$ \\
Residual & 175.623 & 28 & 6.272 & & & $\begin{array}{l}\text { Sig. } \mathrm{F}_{\text {hitung }}<5 \%= \\
\text { Total }\end{array}$ \\
667.871 & 30 & & & & Sangat Signifikan \\
\hline
\end{tabular}

Sumber : Data primer yang diolah, 2017

Dari hasil perhitungan diperoleh $F_{\text {hitung }}=39,240$, sedangkan $F_{\text {tabel }}$ diperoleh sebesar 3,340. Dengan demikian $F_{\text {hitung }}>F_{\text {tabel }}(39,240>3,340)$ dan tingkat signifikansinya $(0,000<0,05)$ berarti secara bersama-sama lingkungan kerja fisik dan lingkungan kerja nonfisik berpengaruh signifikan terhadap kinerja pegawai P.T.
Pegadaian (Persero) Kantor Cabang Palembang.

\section{Hasil Uji t (Uji Parsial)}

Tabel di bawah ini menyajikan hasil Uji t (parsial) untuk variabel lingkungan kerja fisik dan nonfisik:

\section{Hasil Uji t (Uji Parsial)}

Tabel 8 Hasil Uji Parsial (Uji t)

\begin{tabular}{llcll}
\hline \hline Model & $\mathbf{t}_{\text {hitung }}$ & $\mathbf{t}_{\text {tabel }}$ & p-value & Kesimpulan \\
\hline $\mathrm{P}_{\mathrm{x} 1 \mathrm{y}}$ & 6.741 & 1,701 & 0,000 & Sangat Signifikan \\
$\mathrm{P}_{\mathrm{x} 2 \mathrm{y}}$ & 2.589 & 1,701 & 0,015 & Sangat Signifikan \\
\hline
\end{tabular}


Sumber : Data primer yang diolah, 2017

\section{Pengaruh Lingkungan Kerja Fisik terhadap Kinerja Pegawai}

Berdasarkan hasil perhitungan diperoleh angka $t_{\text {hitung }}$ sebesar 6,741 $>t_{\text {tabel }}$ sebesar 1,701 maka Ho ditolak dan $\mathrm{Ha}$ diterima, yang berarti ada pengaruh antara lingkungan kerja fisik terhadap kinerja pegawai P.T. Pegadaian (Persero) Kantor Cabang Palembang. Hal ini tercermin pada angka signifikansi sebesar $0,000<0,05$.

\section{Pengaruh Lingkungan Kerja nonfisik terhadap Kinerja Pegawai}

Berdasarkan hasil perhitungan diperoleh angka $t_{\text {hitung }}$ sebesar 2,589 $>t_{\text {tabel }}$ sebesar 1,701 maka Ho ditolak dan $\mathrm{Ha}$ diterima, yang berarti ada pengaruh antara lingkungan kerja fisik terhadap kinerja pegawai P.T. Pegadaian (Persero) Palembang. Hal ini tercermin pada angka signifikansi sebesar 0,015 $<0,05$.

Tabel di bawah ini menyajikan hasil Uji t (parsial) sebelum dan setelah dimoderasi oleh motivasi:

\section{a. Hasil Uji t (Uji Parsial) Lingkungan Kerja Fisik dan Motivasi}

Tabel 9 Hasil Uji Parsial (Uji t) Tahap 1

\begin{tabular}{llll|cccc}
\hline \multirow{2}{*}{ Model } & \multicolumn{3}{c|}{ Sebelum Dimoderasi } & \multicolumn{3}{c}{ Setelah Dimoderasi } & \multirow{2}{*}{ Kesimpulan } \\
\cline { 2 - 6 } & $\mathbf{t}_{\text {hitung }}$ & $\mathbf{t}_{\text {tabel }}$ & $\mathbf{p}$-value & $\mathbf{t}_{\text {hitung }}$ & $\mathbf{t}_{\text {tabel }}$ & $\mathbf{p - v a l u e}$ & \\
\hline $\mathrm{P}_{\mathrm{x} 1 \mathrm{y}}$ & 5.877 & 1.701 & 0.000 & 5.163 & 1.701 & 0.000 & Sangat Signifikan \\
$\mathrm{P}_{\mathrm{x} 3 \mathrm{y}}$ & 2.302 & 1.701 & 0.000 & 4.509 & 1.701 & 0.000 & Sangat Signifikan \\
$\mathrm{P}_{\mathrm{x} 3 \mathrm{x} 1 \mathrm{y}}$ & & & & -4.198 & 1.701 & 0.000 & Sangat Signifikan \\
\hline
\end{tabular}

Sumber : Data primer yang diolah, 2017

\section{Pengaruh Lingkungan Kerja Fisik terhadap Kinerja Pegawai}

Berdasarkan hasil perhitungan sebelum dimoderasi diperoleh angka $t_{\text {hitung }}$ sebesar 5,887> $\mathrm{t}_{\text {tabel }}$ sebesar 1,701 maka Ho ditolak dan Ha diterima, yang berarti ada pengaruh antara lingkungan kerja fisik terhadap kinerja pegawai P.T. Pegadaian (Persero) Kantor Cabang Palembang. Hal ini tercermin pada angka signifikansi sebesar $0,000<0,05$. Sedangkan setelah dilakukan moderasi hasil perhitungan diperoleh angka $t_{\text {hitung }}$ sebesar 5,163> $t_{\text {tabel }}$ sebesar 1,701 maka Ho ditolak dan Ha diterima, yang berarti ada pengaruh antara lingkungan kerja fisik terhadap kinerja pegawai P.T. Pegadaian (Persero) Palembang dengan dimoderasi motivasi. Hal ini tercermin pada angka signifikansi sebesar $0,000<0,05$.

\section{Pengaruh Motivasi terhadap Kinerja Pegawai}

Berdasarkan hasil perhitungan diperoleh angka $t_{\text {hitung }}$ sebesar 2.302> $t_{\text {tabel }}$ sebesar 1,701 maka Ho ditolak dan Ha diterima, yang berarti ada pengaruh antara motivasi terhadap kinerja pegawai P.T. Pegadaian (Persero) Palembang. Hal ini tercermin pada angka signifikansi sebesar $0,029<0,05$. Sedangkan setelah dilakukan moderasi terhadap kinerja pegawai ternyata hasil perhitungan yang diperoleh motivasi sebesar 4.509> $t_{\text {tabel }}$ sebesar 1,701 maka Ho ditolak dan Ha diterima, yang berarti ada pengaruh antara motivasi terhadap kinerja pegawai P.T. Pegadaian (Persero) Palembang. Hal ini tercermin pada angka signifikansi sebesar $0,000<$ 0,05 . 
Pengaruh Lingkungan Kerja terhadap Kinerja Pegawai dengan Dimoderasi Motivasi

Berdasarkan hasil perhitungan diperoleh angka $t_{\text {hitung }}$ sebesar $-4.198<t_{\text {tabel }}$ sebesar -1,703 maka Ho ditolak dan Ha diterima, yang berarti ada pengaruh antara lingkungan kerja fisik terhadap kinerja pegawai P.T. Pegadaian (Persero) Palembang dengan dimoderasi motivasi. Hal ini tercermin pada angka signifikansi sebesar $0,000<0,05$.

\section{b. Hasil Uji t (Uji Parsial) Lingkungan Kerja Fisik dan Motivasi}

Tabel 10 Hasil Uji Parsial (Uji t) Tahap 2

\begin{tabular}{llll|llll}
\hline \hline \multirow{2}{*}{ Model } & \multicolumn{3}{c|}{ Sebelum Dimoderasi } & \multicolumn{3}{c}{ Setelah Dimoderasi } & \multirow{2}{*}{ Kesimpulan } \\
\cline { 2 - 6 } & $\mathbf{t}_{\text {hitung }}$ & $\mathbf{t}_{\text {tabel }}$ & $\mathbf{p}$-value & $\mathbf{t}_{\text {hitung }}$ & $\mathbf{t}_{\text {tabel }}$ & $\mathbf{p - v a l u e ~}$ & \\
\hline $\mathrm{P}_{\mathrm{x} 2 \mathrm{y}}$ & 1.235 & 1.701 & 0.227 & 3.699 & 1.701 & 0.001 & Sangat Signifikan \\
$\mathrm{P}_{\mathrm{x} 3 \mathrm{y}}$ & 2.295 & 1.701 & 0.029 & 3.888 & 1.701 & 0.001 & Sangat Signifikan \\
$\mathrm{P}_{\mathrm{x} 3 \mathrm{x} 2 \mathrm{y}}$ & & & & -3.524 & 1.701 & 0.002 & Sangat Signifikan \\
\hline
\end{tabular}

Sumber : Data primer yang diolah, 2017

Pengaruh Lingkungan Kerja nonfisik terhadap Kinerja Pegawai

Berdasarkan hasil perhitungan diperoleh angka $t_{\text {hitung }}$ sebesar $1.235<t_{\text {tabel }}$ sebesar 1,701 maka Ho diterima dan $\mathrm{Ha}$ ditolak, yang berarti tidak ada pengaruh antara lingkungan kerja nonfisik terhadap kinerja pegawai P.T. Pegadaian (Persero) Kantor Cabang Palembang. Hal ini tercermin pada angka signifikansi sebesar $0,227>0,05$. Setelah dilakukan moderasi hasil perhitungan diperoleh angka $t_{\text {hitung }}$ sebesar 3.699> $t_{\text {tabel }}$ sebesar 1,701 maka Ho ditolak dan Ha diterima, yang berarti ada pengaruh antara lingkungan kerja fisik terhadap kinerja pegawai P.T. Pegadaian (Persero) Palembang dengan dimoderasi motivasi. Hal ini tercermin pada angka signifikansi sebesar $0,001<0,05$.

Pengaruh Motivasi terhadap Kinerja Pegawai

Berdasarkan hasil perhitungan diperoleh angka $t_{\text {hitung }}$ sebesar 2.295> $t_{\text {tabel }}$ sebesar 1,701 maka Ho ditolak dan $\mathrm{Ha}$ diterima, yang berarti ada pengaruh antara motivasi terhadap kinerja pegawai P.T. Pegadaian (Persero) Palembang. Hal ini tercermin pada angka signifikansi sebesar $0,029<0,05$. Sedangkan setelah dilakukan moderasi ternyata hasil perhitungan motivasi diperoleh angka $t_{\text {hitung }}$ sebesar 3.888> $t_{\text {tabel }}$ sebesar 1,701 maka Ho ditolak dan Ha diterima, yang berarti ada pengaruh antara motivasi terhadap kinerja pegawai P.T. Pegadaian (Persero) Palembang. Hal ini tercermin pada angka signifikansi sebesar $0,001<0,05$.

\section{Pengaruh Lingkungan Kerja Terhadap} Kinerja Pegawai Dengan Dimoderasi Motivasi

Berdasarkan hasil perhitungan diperoleh angka $t_{\text {hitung }}$ sebesar $-3.524<t_{\text {tabel }}$ sebesar -1,703 maka Ho ditolak dan Ha diterima, yang berarti ada pengaruh antara lingkungan kerja fisik terhadap kinerja pegawai P.T. Pegadaian (Persero) Palembang dengan dimoderasi motivasi. Hal ini tercermin pada angka signifikansi sebesar $0,002<0,05$.

\section{A. Pembahasan}

1. Pengaruh Lingkungan Kerja Fisik dan Nonfisik Secara Bersama-sama Terhadap Kinerja Pegawai

Dari hasil perhitungan diperoleh $F_{\text {hitung }}=39,240$, sedangkan $F_{\text {tabel }}$ diperoleh sebesar 3,340. Dengan demikian $F_{\text {hitung }}>F_{\text {tabel }}(39,240>3,340)$ dan tingkat 
signifikansinya $(0,000<0,05)$ berarti secara bersama-sama lingkungan kerja fisik dan lingkungan kerja nonfisik berpengaruh signifikan terhadap kinerja pegawai P.T. Pegadaian (Persero) Kantor Cabang Palembang. Bukti nyata yang dapat ditunjukkan bahwa lingkungan kerja fisik dan nonfisik dapat mempengaruhi kinerja pegawai karena jika lingkungan kerja fisik berupa tata ruang, penerangan, tingkat kebisingan didesain dengan baik tentu yang mendatangkan kenyamanan sehingga dapat menunjang suasana kerja. Begitu pula dengan lingkungan kerja nonfisik yang biasanya melibatkan tingkat emosional pegawai seperti hubungan kerja antara bawahan dan hubungan bawahan dan atasan jika terbina dengan baik dan harmonis sehingga akan timbul rasa kekeluargaan yang akan saling melengkapi kekurangan untuk menciptakan suasana kerja yang nyaman. Keadaan ini secara otomatis akan berpengaruh terhadap kinerja pegawai.

\section{Pengaruh Lingkungan Kerja Fisik Terhadap Kinerja Pegawai}

Berdasarkan hasil analisis statistik inferensial dengan menggunakan analisis regresi, variabel lingkungan kerja fisik memiliki nilai $t_{\text {hitung }}$ sebesar 6,741 dan $t_{\text {tabel }}$ sebesar 1,701 dengan probabilitas signifikansi sebesar 0,000 lebih kecil dari ( $\alpha$ ) 0,05 sehingga variabel lingkungan kerja fisik memiliki pengaruh yang sangat signifikan terhadap kinerja pegawai. Hasil analisis regresi menunjukkan bahwa variabel lingkungan kerja fisik merupakan salah satu faktor yang memiliki pengaruh secara langsung yang positif dan signifikan terhadap kinerja pegawai P.T. Pegadaian (Persero) Kantor Cabang Palembang.

Hasil ini sesuai dengan penelitian Cintia dan Gilang (2016) yang bertujuan untuk melihat pengaruh lingkungan kerja fisik terhadap kinerja karyawan di KPPN Bandung I. Penelitian ini bersifat deskriptif dengan menggunakan regresi linier software SPSS versi 16.0 sebagai alat ukur statistik. Hasil penelitian terhadap 45 responden menunjukkan bahwa 44,9\% lingkungan kerja fisik seperti peralatan kerja, ventilasi, kebisingan, pencahayaan, dan tata letak berpengaruh parsial terhadap kinerja karyawan. Oleh karena itu, hasil penelitian ini menunjukkan bahwa baik secara parsial maupun simultan, lingkungan kerja fisik berdampak signifikan terhadap kinerja karyawan di Bandung KPPN I.

Lingkungan kerja fisik merupakan salah satu faktor pendukung menuju peningkatan kinerja pegawai karena lingkungan yang konduksif menyebabkan timbulnya rasa nyaman dalam bekerja. Seperti, tata ruang, pencahayaan dan tingkat kebisingan yang akan mempengaruhi suasana kerja.

\section{Pengaruh Lingkungan Kerja Nonfisik Terhadap Kinerja Pegawai}

Berdasarkan hasil analisis statistik inferensial dengan menggunakan analisis regresi, variabel lingkungan kerja fisik memiliki nilai $\mathrm{t}_{\text {hitung }}$ sebesar 2,589 dan $\mathrm{t}_{\text {tabel }}$ sebesar 1,701 dengan probabilitas signifikansi sebesar 0,015 lebih kecil dari ( $\alpha$ ) 0,05 sehingga variabel lingkungan kerja nonfisik memiliki pengaruh yang signifikan terhadap kinerja pegawai. Hasil analisis regresi menunjukkan bahwa variabel lingkungan kerja nonfisik merupakan salah satu faktor yang memiliki pengaruh secara langsung yang positif dan signifikan terhadap kinerja pegawai P.T. Pegadaian (Persero) Kantor Cabang Palembang. 
Hasil ini tidak sesuai dengan penelitian yang dilakukan oleh Prasidya dkk (2014). Penelitian ini bertujuan untuk mendeskripsikan dan menjelaskan pengaruh lingkungan kerja dari suatu perusahaan terhadap kinerja karyawan. Jenis penelitian yang digunakan dalam penelitian skripsi ini adalah penelitian penjelasan (explanatory research) dengan pendekatan kuantitatif. Penelitian ini dilakukan pada PT. Telkomsel Area III Jawa-Bali Nusra di Surabaya. Populasi dalam penelitian ini adalah karyawan dari bagian finance and administration dan marketing area departement pada PT. Telkomsel Area III Jawa-Bali Nusra di Surabaya, dengan jumlah 310 karyawan dan jumlah sampel sebesar 75. Teknik analisis data yang digunakan adalah analisis statistik deskriptif dan analisis statistik inferensial dengan menggunakan analisis regresi linier berganda. Berdasarkan hasil penelitian tidak ada pengaruh secara signifikan antara variabel lingkungan kerja non fisik terhadap kinerja karyawan (Y) karena nilai sig lebih besar dari $0,05(0,081>0,05)$ atau koefisien regresi sebesar 20,2\%.

Setiap pegawai dalam bekerja membutuhkan lingkungan kerja nonfisik terutama untuk membina hubungan yang baik antara atasan-bawahan dan sesama rekan kerja. Misalnya, komunikasi karena kinerja pegawai dapat berjalan lancar harus didukung oleh lancarnya komunikasi.

\section{Pengaruh Lingkungan Kerja Fisik dan Motivasi Secara Parsial Terhadap Kinerja Pegawai}

Berdasarkan hasil analisis statistik inferensial dengan menggunakan analisis regresi, variabel lingkungan kerja fisik memiliki nilai $t_{\text {hitung }}$ sebesar 5,877 dan $t_{\text {tabel }}$ sebesar 1,701 dengan probabilitas signifikansi sebesar 0,000 lebih kecil dari ( $\alpha$ ) 0,05 . Sedangkan motivasi memiliki nilai $t_{\text {hitung }}$ sebesar 2,302 dan $t_{\text {tabel }}$ sebesar 1,701 dengan probabilitas signifikansi sebesar 0,029 lebih kecil dari $(\alpha)$ 0,05 sehingga variabel lingkungan kerja fisik dan motivasi secara parsial memiliki pengaruh yang sangat signifikan terhadap kinerja pegawai P.T. Pegadaian (Persero) Kantor Cabang Palembang. Setelah dilakukan moderasi melalui motivasi terdapat perubahan yang signifikan terhadap kinerja pegawai.

Baik lingkungan kerja fisik dan motivasi sangat mendukung setiap pencapaian kinerja pegawai. Lingkungan kerja fisik yang nyaman akan membuat setiap pegawai menjadi lebih betah dalam bekerja. Sedangkan motivasi yang merupakan pendorong semangat dalam bekerja sangat diperlukan untuk meminimalisir kebosanan dan monotonitas dalam bekerja.

\section{Pengaruh Lingkungan Kerja Nonfisik dan Motivasi Secara Parsial Terhadap Kinerja Pegawai}

Berdasarkan hasil analisis statistik inferensial dengan menggunakan analisis regresi, variabel lingkungan kerja nonfisik memiliki nilai $t_{\text {hitung }}$ sebesar 1,235 dan $t_{\text {tabel }}$ sebesar 1,701 dengan probabilitas signifikansi sebesar 0,227 lebih besar dari ( $\alpha)$ 0,05. Ini berarti bahwa lingkungan kerja nonfisik tidak berpengaruh terhadap kinerja pegawai. Sedangkan motivasi memiliki nilai $t_{\text {hitung }}$ sebesar 2,302 dan $t_{\text {tabel }}$ sebesar 1,701 dengan probabilitas signifikansi sebesar 0,029 lebih kecil dari ( $\alpha$ ) 0,05 sehingga variabel lingkungan kerja fisik tidak berpengaruh terhadap kinerja pegawai dan motivasi secara parsial memiliki pengaruh yang signifikan 
terhadap kinerja pegawai P.T. Pegadaian (Persero) Kantor Cabang Palembang. Sedangkan setelah dilakukan uji t (parsial) antara lingkungan kerja nonfisik dengan melalui interaksi motivasi ternyata terjadi sebaliknya yaitu lingkungan kerja nonfisik menjadi berpengaruh terhadap peningkatan kinerja, Sedangkan motivasi berpengaruh terhadap kinerja pegawai.

\section{Pengaruh Lingkungan Fisik Dengan Dimoderasi Oleh Motivasi Terhadap Kinerja Pegawai}

Berdasarkan hasil analisis statistik inferensial dengan menggunakan analisis regresi, variabel lingkungan kerja fisik memiliki nilai $t_{\text {hitung }}$ sebesar 5,163 dan $t_{\text {tabel }}$ sebesar 1,701 dengan probabilitas signifikansi sebesar 0,000 , sehingga variabel lingkungan kerja fisik memiliki pengaruh yang sangat signifikan terhadap kinerja pegawai. Sedangkan motivasi memiliki nilai $t_{\text {hitung }}$ sebesar 4,509 dan $t_{\text {tabel }}$ sebesar 1,701 dengan probabilitas signifikansi sebesar 0,000 lebih kecil dari ( $\alpha)$ 0,05. Setelah dilakukan interaksi lingkungan kerja fisik dengan dimoderasi oleh motivasi maka hasil analisis regresi diperoleh $-4,198$ dengan tingkat probabilitas signifikansi sebesar 0,000 lebih kecil dari $(\alpha)$ 0,05. Hal ini menunjukkan bahwa variabel lingkungan kerja fisik dengan dimoderasi oleh motivasi berpengaruh sangat signifikan terhadap kinerja pegawai.

Dari hasil penelitian tersebut menunjukkan bahwa motivasi memberikan kontribusi yang cukup besar terhadap kinerja pegawai P.T. Pegadaian (Persero) Kantor Cabang Palembang. Hal ini menggambarkan bahwa dengan adanya motivasi yang tinggi maka menimbulkan dorongan yang tinggi untuk mencapai suatu keinginan atau kebutuhan. Hal ini memicu gairah kerja yang tinggi dalam melaksanakan tugas dan tanggung jawabnya. Gairah kerja yang tinggi membuat setiap pegawai akan berusaha sebaik mungkin dalam melakukan pekerjaannya, sehingga dapat memberikan hasil kerja yang memuaskan atau dengan kata lain kinerja pegawai mengalami peningkatan.

\section{Pengaruh Lingkungan Nonfisik Dengan Dimoderasi Oleh Motivasi Terhadap Kinerja Pegawai}

Berdasarkan hasil analisis statistik inferensial dengan menggunakan analisis regresi, variabel lingkungan kerja nonfisik memiliki nilai $t_{\text {hitung }}$ sebesar 3,699 dan $t_{\text {tabel }}$ sebesar 1,701 dengan probabilitas signifikansi sebesar 0,001 , sehingga variabel lingkungan kerja nonfisik memiliki pengaruh yang sangat signifikan terhadap kinerja pegawai. Sedangkan motivasi memiliki nilai $t_{\text {hitung }}$ sebesar 3,888 dan $t_{\text {tabel }}$ sebesar 1,701 dengan probabilitas signifikansi sebesar 0,001 lebih kecil dari (a) 0,05. Setelah dilakukan interaksi lingkungan kerja nonfisik dengan dimoderasi oleh motivasi maka hasil analisis regresi diperoleh -3,524 dengan tingkat probabilitas signifikansi sebesar 0,002 lebih kecil dari $(\alpha)$ 0,05. Hal ini menunjukkan bahwa variabel lingkungan kerja nonfisik dengan dimoderasi oleh motivasi berpengaruh sangat signifikan terhadap kinerja pegawai.

Sebelum dilakukan moderasi, variabel lingkungan kerja nonfisik yang tidak berpengaruh terhadap kinerja pegawai dengan nilai $t_{\text {hitung }}$ sebesar 1,235 dan $t_{\text {tabel }}$ sebesar 1,701 dengan probabilitas signifikansi sebesar 0,227 lebih besar dari (a) 0,05 . Setelah dimoderasi oleh motivasi maka hasil yang diperoleh sebesar 3,699 menunjukkan keadaan yang sebaliknya. 
Hal ini menggambarkan bahwa variabel motivasi sangat berpengaruh terhadap lingkungan kerja nonfisik karena berfungsi memperkuat hubungan lingkungan kerja nonfisik terhadap kinerja pegawai.

Analisis dalam penelitian ini menunjukkan bahwa terdapat persepsi yang baik dari pegawai terhadap motivasi. Artinya semakin tinggi persepsi pegawai mengenai motivasi, maka kinerja pegawai P.T. Pegadaian (Persero) Kantor Cabang Palembang akan mengalami peningkatan, hal tersebut dikarenakan setelah dimoderasi oleh motivasi terdapat peningkatan kinerja pegawai yang sangat signifikan.

\section{KESIMPULAN DAN SARAN Kesimpulan}

Berdasarkan hasil analisis data yang telah dilakukan dalam penelitian ini, diperoleh kesimpulan sebagai berikut:

1. Ada pengaruh yang signifikan antara lingkungan kerja fisik secara parsial terhadap kinerja pegawai P.T. Pegadaian (Persero) Kantor Cabang Palembang.

2. Ada pengaruh yang signifikan lingkungan kerja nonfisik secara parsial terhadap kinerja pegawai P.T. Pegadaian (Persero) Kantor Cabang Palembang.

3. Ada pengaruh yang signifikan lingkungan kerja dan lingkungan kerja nonfisik secara bersama-sama terhadap kinerja pegawai P.T. Pegadaian (Persero) Kantor Cabang Palembang.

4. Ada pengaruh yang signifikan lingkungan kerja fisik dengan dimoderasi motivasi terhadap kinerja pegawai P.T. Pegadaian (Persero) Kantor Cabang Palembang.

5. Ada pengaruh yang signifikan lingkungan kerja nonfisik dengan dimoderasi motivasi terhadap kinerja pegawai P.T. Pegadaian (Persero) Kantor Cabang Palembang.

\section{Saran}

Dari pembahasan dan kesimpulan maka ada beberapa saran yang dapat diberikan untuk mendukung pencapaian kinerja pegawai P.T. Pegadaian (Persero) Kantor Cabang Palembang, yaitu:

a. Pimpinan PT. Pegadaian (Persero) Kantor Cabang Palembang dapat berperan sebagai mediator dalam menjalin hubungan baik bagi dirinya maupun antar pegawaisehingga dapat menciptakan suasana kerja yang lebih menyenangkan, misalnya dengan melakukan kegiatan yang bertujuan mengikat keeratan hubungan antar pegawai.

b. Walaupun telah terbukti dengan motivasi dapat meningkatkan kinerja pegawai dan memperkuat lingkungan kerja tetapi pimpinan PT. Pegadaian (Persero) Kantor Cabang Palembang dapat terus memotivasi dan menumbuhkan semangat para pegawai dengan melakukan sesuatu yang baru misalnya membuat suatu tantangan pekerjaan agar para pegawai dapat bersaing secara sehat yang hal ini akan secara otomatis dapat memotivasi para pegawai.

c. Ruangan yang terlalu sempit perlu dicarikan solusi lain termasuk pewarnaan dan tingkat kebisingan, terutama untuk bagian pelayanan nasabah dan humas. 


\section{DAFTAR PUSTAKA}

Eldaa Cintia dan Alini Gilang. 2016. Pengaruh Lingkungan Kerja Fisik dan Nonfisik Terhadap Kinerja Karyawan Pada KPPN Bandung I. (http://.portalgaruda.org/article.php L(diakses 15 April 2016).

Ghozali, Imam. 2011. Aplikasi Analisis Multivariate dengan Program IBM SPSS 19. Edisi kelima. Semarang: Badan Penerbit Universitas Diponegoro.

Koesmono,Teman. 2007. Pengaruh Kepemimpinan dan Tuntutan Tugas Terhadap Komitmen Organisasi dengan Variabel Moderasi Motivasi Perawat Rumah Sakit Swasta Surabaya. Jurnalmanajemen.petra.ac.id/index. $\mathrm{php} / \mathrm{man} / \mathrm{article} / \quad$ view/16633. (diakses 15 April 2016)

Mangkunegara, Anwar Prabu. 2014. Evaluasi Kinerja SDM. Cetakan Ketujuh. Bandung: Refika Aditama Marwansyah. 2012. Maanajemen Sumber Daya Manusia. Edisi Kedua. Bandung: Alfabeta.

Prasidya, Yacinda Chresstela, Orianggono, Djamhur Hamid dan Ika Ruhana, 2014, Pengaruh lingkungan kerja Fisik dan non fisik Terhadap Kinerja Karyawan (studi pada karyawan PT. Telkomsel area III Jawa-Bali Nusra diSurabaya), Jurnal Administrasi Bisnis (JAB) Vol. 8 No. 2 Maret, administrasibisnis.studentjournal.u b.ac.id (https://media.neliti.com/media/ publications/80670-ID-pengaruh- lingkungan-kerja-fisik-dan-

non.pdf) (diakses 5 Februari 2018)

Sanusi, Anwar. 2014. Metodologi Penelitian Bisnis. Jakarta: Penerbit Salemba Empat.

Sedarmayanti. 2011. Tata Kerja Dan Produktivitas Kerja ( Suatu Tinjauan Aspek Ergonomi atau Kaitan Antara Manusia dengan Lingkungan Kerjanya). Bandung: CV. Mandar Maju.

Shein, Edgar H. 2010. Organizational Culture and Leaderships: Edition 4. John Wiley \& Son, Ltd. Edition 4

Singgih, Santoso. 2010. Statistik Parametrik Konsep dan Aplikasi Dengan SPSS. Jakarta: Penerbit PT Elex Media Komputindo Kelompok Gramedia, Anggota IKAPI.

Sugiyono. 2017. Metode Penelitian Kuantitatif, Kualitatif Dan $R \& D$. Cetakan Kedua puluh tiga. Bandung : CV. Alfabeta.

Sutrisno, Edy. 2015. Manajemen Sumber Daya Manusia. Cetakan Ketujuh. Jakarta: Kencana. 